\title{
Analisis Faktor-Faktor yang Mempengaruhi Penyebaran Penyakit Demam Berdarah Dengue (Dbd) di Provinsi Jawa Tengah dengan Metode Spatial Autoregressive Model dan Spatial Durbin Model
}

\author{
Arkadina Prismatika Noviandini Taryono ${ }^{1}$, Dwi Ispriyanti ${ }^{2}$, and Alan Prahutama ${ }^{3}$ \\ ${ }^{1}$ Mahasiswa Jurusan Statistika FSM Universitas Diponegoro \\ ${ }^{2,3}$ Staff Pengajar Jurusan Statistika FSM Universitas Diponegoro \\ arkadinaprismatika@gmail.com
}

\begin{abstract}
Dengue Hemorrhagic Fever is one of the major public health problems in Indonesia. From year to year, DHF causes Extraordinary Event in most parts of Indonesia, especially Central Java. Central Java consists of 35 districts or cities where each region is close to each other. Spatial regression is an analysis that suspects the influence of independent variables on the dependent variables with the influences of the region inside. In spatial regression modeling, there are spatial autoregressive model (SAR), spatial error model (SEM) and spatial autoregressive moving average (SARMA). Spatial durbin model is the development of SAR where the dependent and independent variable have spatial influence. In this research dependent variable used is number of DHF sufferers. The independent variables observed are population density, number of hospitals, residents and health centers, and mean years of schooling. From the multiple regression model test, the variables that significantly affect the spread of DHF disease are the population and mean years of schooling. Moran's I test results stated that there are spatial dependencies between dependent and independent variables. The best model produced is the SAR model because it has the smallest AIC value of 49.61
\end{abstract}

Keywords : DHF, spatial autoregressive model, spatial Durbin model

\section{Pendahuluan}

Penyakit Demam Berdarah Dengue (DBD) merupakan salah satu masalah kesehatan masyarakat yang utama di Indonesia. Jumlah penderita dan luas daerah penyebarannya semakin bertambah seiring dengan meningkatnya mobilitas dan kepadatan penduduk. Dari tahun ke tahun kejadian DBD seringkali mengakibatkan Kejadian Luar Biasa (KLB) di hampir sebagian besar wilayah Indonesia termasuk di Jawa Tengah.

Banyak faktor yang mempengaruhi penyebaran penyakit DBD antara lain faktor host (kerentanan), faktor lingkungan, kondisi demografi, letak geografis dan jenis nyamuk. Jawa Tengah terdiri dari 35 kabupaten/kota dimana masing-masing daerah saling berdekatan antara satu dengan yang lainnya. Metode stastistika yang digunakan untuk menganalisis faktor-faktor apa saja yang mempengaruhi penyebaran penyakit DBD dengan melibatkan unsur wilayah didalamnya adalah regresi spasial. 
Dalam pemodelan regresi spasial terdapat model spasial autoregressive model (SAR), spasial error model (SEM) serta spasial autoregressive moving average (SARMA). Spasial durbin model merupakan pengembangan dari spasial autoregressive model dimana pengaruh spasial tidak hanya pada variabel dependen tetapi juga pada variabel independen, LeSage[5].

Dalam penelitian ini metode yang akan digunakan oleh peneliti adalah Spatial Autoregressive Model (SAR) dan Spatial Durbin Model (SDM) dengan pembobot Queen contiguity. Variabel dependen dalam penelitian ini adalah jumlah penderita DBD di kabupaten/kota Jawa Tengah, sedangkan variabel independen yang digunakan adalah jumlah penduduk, kepadatan penduduk, jumlah rumah sakit, jumlah puskesmas dan ratarata lama sekolah di kabupaten/kota Jawa Tengah.

\section{Tinjauan Pustaka}

\subsection{Demam Berdarah Dengue (DBD)}

Demam dengue merupakan penyakit demam akut yang disebabkan oleh virus dengue dan disebarkan melalui perantara nyamuk Aedes aegypti yang telah terinfeksi dengan virus dengue tersebut. Masa inkubasi virus Dengue dalam manusia (inkubasi intrinsik) berkisar antara 3 sampai 14 hari sebelum gejala muncul, gejala klinis rata-rata muncul pada hari keempat sampai hari ketujuh, sedangkan masa inkubasi ekstrinsik (di dalam tubuh nyamuk) berlangsung sekitar 8-10 hari.

\subsection{Regresi Linier Berganda}

Regresi linier berganda merupakan perluasan dari model regresi linier sederhana dengan lebih dari satu variabel independen, Montgomery \& Runger[7]. Persamaan regresi linier berganda dengan $k$ variabel independen adalah sebagai berikut:

$$
y_{i}=\beta_{0}+\beta_{1} x_{i 1}+\beta_{2} x_{i 2}+\cdots+\beta_{k} x_{i k}+\varepsilon_{i}
$$

Untuk mengestimasi parameter regresi berganda digunakan metode kuadrat terkecil (Ordinary Least Square). Diperoleh estimator kuadrat terkecil dari $\boldsymbol{\beta}$ adalah sebagai berikut:

$$
\widehat{\boldsymbol{\beta}}=\left(\boldsymbol{X}^{T} \boldsymbol{X}\right)^{-1}\left(\boldsymbol{X}^{T} \boldsymbol{y}\right)
$$

\subsubsection{Pengujian Model Regresi}

\section{(a) Uji Signifikansi Regresi}

Menurut Montgomery dan Runger[7], Uji signifikansi regresi ini dimaksudkan untuk menentukan apakah ada hubungan linier antara variabel dependen dan variabel independen. 
Hipotesis:

$\mathrm{H}_{0}: \beta_{1}=\beta_{2}=\ldots=\beta_{k}=0$

$\mathrm{H}_{1}: \beta_{j} \neq 0$ untuk paling sedikit satu $j$

Statistik Uji:

$$
F_{\text {hitung }}=\frac{S S R / k}{S S E /(n-k-1)}
$$

Keputusan: $\mathrm{H}_{0}$ ditolak jika nilai $F_{\text {hitung }}>F_{a, k, n-k-1}$

\section{(b) Uji Koefisien Regresi Secara Individual}

Pengujian secara individu digunakan untuk menguji ada atau tidak pengaruh masing-masing variabel independen terhadap model regresi, Montgomery \& Runger[7].

Hipotesis:

$\mathrm{H}_{0}: \beta_{j}=0 \quad$ (Parameter tidak signifikan)

$\mathrm{H}_{1}: \beta_{j} \neq 0$ (Parameter signifikan)

Statistik Uji:

$$
t_{\text {hitung }}=\frac{\hat{\beta}_{j}}{\operatorname{Se}\left(\hat{\beta}_{j}\right)}
$$

Keputusan: $\mathrm{H}_{0}$ ditolak jika nilai $\left|t_{\text {hitung }}\right|>t_{\alpha / 2, n-k-1}$

\subsubsection{Uji Asumsi Regresi}

\section{(a) Asumsi Normalitas}

Secara visual uji normalitas dapat dideteksi dengan melihat penyebaran data (titik) pada sumbu diagonal dari grafik P-P plot. Jika data menyebar disekitar garis diagonal dan mengikuti arah garis diagonal maka model regresi memenuhi asumsi normalitas.

Uji formal untuk mengetahui apakah sampel penelitian merupakan jenis distribusi normal atau tidak adalah dengan menggunakan Kolmogorov-Smirnov Goodness of Fit Test terhadap masing-masing variabel. Data terdiri dari sampel acak $\mathrm{X}_{1}, \mathrm{X}_{2}, \ldots, \mathrm{X}_{\mathrm{n}}$ berukuran $n$ dengan distribusi yang belum diketahui jenisnya yang dinotasikan $F(x)$ (Conover, 1980).

\section{Hipotesis:}

$\mathrm{H}_{0}: F(x)=F^{*}(x)$ (data sampel berdistribusi normal)

$\mathrm{H}_{1}: F(x) \neq F^{*}(x)$ (data sampel tidak berdistribusi normal)

Statistik Uji:

$$
T={ }_{x}^{\text {sup }}\left|F^{*}(x)-S(x)\right|
$$

dimana: $\mathrm{S}(\mathrm{x}) \quad=$ Fungsi distribusi frekuensi kumulatif 


$$
\mathrm{F}^{*}(\mathrm{x})=\text { Probabilitas kumulatif distribusi normal }
$$

Keputusan: $\mathrm{H}_{0}$ ditolak jika $\mathrm{T}>q_{1-\alpha}$ dimana $q_{1-\alpha}$ merupakan nilai kritis yang diperoleh dari tabel Kolmogorov-Smirnov.

\section{(b) Asumsi Non-Autokorelasi}

Untuk mendeteksi adanya autokorelasi antar galat atau tidak, digunakan pengujian metode Durbin-Watson, Gujarati[2].

\section{Hipotesis}

$\mathrm{H}_{0}$ : Tidak ada autokorelasi antar galat

$\mathrm{H}_{1}$ : Ada autokorelasi antar galat

\section{Statistik Uji:}

$$
d=\frac{\sum_{t=2}^{t=N}\left(e_{t}-e_{t-1}\right)^{2}}{\sum_{t=1}^{t=N} e_{t}^{2}}
$$

Keputusan: Menerima $\mathrm{H}_{0}$ jika $\mathrm{d}>\mathrm{d}_{\mathrm{U}}$ atau $\mathrm{d}<\left(4-\mathrm{d}_{\mathrm{U}}\right)$. Menolah $\mathrm{H}_{0}$ jika $\mathrm{d}<\mathrm{d}_{\mathrm{L}}$ atau $\mathrm{d}>\left(4-\mathrm{d}_{\mathrm{L}}\right)$. Tanpa keputusan jika $\mathrm{d}_{\mathrm{L}} \leq \mathrm{d} \leq \mathrm{d}_{\mathrm{U}}$ atau $\left(4-\mathrm{d}_{\mathrm{U}}\right) \leq \mathrm{d} \leq\left(4-\mathrm{d}_{\mathrm{L}}\right)$. Dimana $\mathrm{d}_{\mathrm{U}}$ adalah batas atas dan $\mathrm{d}_{\mathrm{L}}$ adalah batas bawah yang diperoleh dari tabel Durbin-Watson.

\section{(c) Asumsi Multikolinearitas}

Menurut Kleinbaum et al[4], tolerance and variance inflation factor (VIF) adalah metode yang biasa digunakan untuk menghitung hubungan linear antar variabel independen dalam regresi berganda. Jika nilai VIF dari suatu variabel melebihi 10, maka dikatakan variabel tersebut berkorelasi sangat tinggi. Statistik uji untuk VIF adalah sebagai berikut:

$$
V I F_{j}=\frac{1}{1-R_{j}^{2}} \quad j=1,2, \ldots, k
$$

dimana : $R_{j}^{2}=$ Nilai koefisien determinasi pada variabel ke-j

\subsection{Regresi Spasial}

Regresi spasial adalah model yang terbentuk dari regresi klasik yang mendapatkan pengaruh spasial (lokasi) didalamnya. Menurut Lesage[5], model umum regresi spasial dapat dituliskan sebagai berikut:

$$
\begin{gathered}
\boldsymbol{y}=\rho \boldsymbol{W}_{\mathbf{1}} \boldsymbol{y}+\boldsymbol{X} \boldsymbol{\beta}+\boldsymbol{u} \\
\boldsymbol{u}=\lambda \boldsymbol{W}_{\mathbf{2}} \boldsymbol{u}+\boldsymbol{\varepsilon}, \boldsymbol{\varepsilon} \sim \boldsymbol{N}\left(0, \sigma_{\varepsilon}^{2} \boldsymbol{I}_{n}\right)
\end{gathered}
$$

dengan: 
$P \quad=$ koefisien spasial lag dari variabel dependen

$\boldsymbol{W}_{1}, \boldsymbol{W}_{2}=$ Matriks pembobot spasial yang berukuran $\mathrm{n} \times \mathrm{n}$

$\Lambda \quad=$ Koefisien autoregresi galat spasial

$\mathbf{u}=$ Vektor error yang mempunyai efek spasial dengan ukuran $\mathrm{nx} 1$

$\boldsymbol{\varepsilon} \quad=$ Vektor error dengan ukuran $\mathrm{nx} 1$

Dari persamaan model umum regresi spasial dapat dibentuk beberapa model lain sebagai berikut:

1. Jika $\rho=0$ dan $\lambda=0$ maka disebut model regresi linier klasik dengan persamaan yang terbentuk adalah:

$$
\boldsymbol{y}=\boldsymbol{X} \boldsymbol{\beta}+\boldsymbol{\varepsilon}
$$

2. Jika $\rho \neq 0$ dan $\lambda=0$ disebut regresi Spatial Autoregressive Model (SAR) dengan persamaan yang terbentuk adalah:

$$
\boldsymbol{y}=\rho \boldsymbol{W}_{\mathbf{1}} \boldsymbol{y}+\boldsymbol{X} \boldsymbol{\beta}+\boldsymbol{\varepsilon}
$$

3. Jika $\rho=0$ dan $\lambda \neq 0$ disebut regresi Spatial Error Model (SEM) dengan persamaan yang terbentuk adalah:

$$
\begin{gathered}
\boldsymbol{y}=\boldsymbol{X} \boldsymbol{\beta}+\boldsymbol{u} \\
\boldsymbol{u}=\lambda \boldsymbol{W}_{\mathbf{2}} \boldsymbol{u}+\boldsymbol{\varepsilon}
\end{gathered}
$$

4. Jika $\rho \neq 0$ dan $\lambda \neq 0$ disebut Spatial Autoregressive Moving Average (SARMA) dengan persamaan yang terbentuk adalah:

$$
\begin{gathered}
\boldsymbol{y}=\rho \boldsymbol{W}_{\mathbf{1}} \boldsymbol{y}+\boldsymbol{X} \boldsymbol{\beta}+\boldsymbol{u} \\
\boldsymbol{u}=\lambda \boldsymbol{W}_{\mathbf{2}} \boldsymbol{u}+\boldsymbol{\varepsilon}
\end{gathered}
$$

\subsection{Uji Efek Spasial}

\section{(a) Uji Moran's I}

Menurut Goodchild (1986), untuk mengetahui apakah ada autokorelasi atau ketergantungan spasial antar lokasi maka dilakukan uji autokorelasi spasial dengan menggunakan metode Moran's $I$.

Hipotesis:

$\mathrm{H}_{0}$ : Ada autokorelasi spasial antar lokasi

$\mathrm{H}_{1}$ : Tidak ada autokorelasi spasial antar lokasi

Statistik Uji:

$$
Z_{\text {hitung }}=\frac{I-E(I)}{\sqrt{\operatorname{var}(I)}}
$$


dimana:

$$
\begin{aligned}
& I=\frac{\sum_{i=1}^{n} \sum_{j=1}^{n} w_{i j} c_{i j}}{S^{2} \sum_{i=1}^{n} \sum_{j=1}^{n} w_{i j}} \\
& E(I)=I_{0}=-\frac{1}{n-1} \\
& \operatorname{var}(I)=\frac{n^{2} S_{1}-n S_{2}+3 S_{0}^{2}}{\left(n^{2}-1\right) S_{0}^{2}}-[E(I)]^{2} \\
& c_{i j}=\left(x_{i}-\bar{x}\right)\left(x_{j}-\bar{x}\right) \\
& s^{2}=\frac{\sum_{i=1}^{n}\left(x_{i}-\bar{x}\right)^{2}}{n} \\
& S_{0}=\sum_{i=1}^{n} \sum_{j=1}^{n} w_{i j} \\
& S_{1}=\frac{1}{2} \sum_{i \neq j}^{n}\left(w_{i j}+w_{j i}\right)^{2} \\
& S_{2}=\sum_{i \neq j}^{n}\left(w_{i 0}+w_{0 i}\right)^{2} \\
& w_{i 0}=\sum_{j=1}^{n} w_{i j} \\
& w_{j=1}^{n} w_{j i}
\end{aligned}
$$

Keputusan: $\mathrm{H}_{0}$ ditolak jika $\left|Z_{\text {hitung }}\right|>Z_{\alpha / 2}$

\section{(b) Uji Heterogenitas Spasial}

Untuk mengetahui apakah ada heterogenitas spasial maka dilakukan uji heterogenitas spasial dengan menggunakan Breusch-Pagan Test (Anselin, 1988).

Hipotesis:

$\mathrm{H}_{0}: \sigma_{1}{ }^{2}=\sigma_{2}{ }^{2}=\cdots=\sigma_{n}{ }^{2}=\sigma^{2}$ (terdapat homogenitas)

$\mathrm{H}_{1}$ : Minimal terdapat satu $\sigma_{i}^{2} \neq \sigma^{2}$ (terdapat heterogenitas)

Statistik Uji Breusch-Pagan test:

$$
B P=\frac{1}{2}\left[\mathbf{f}^{\mathrm{T}} \mathbf{Z}\left(\mathbf{Z}^{\mathrm{T}} \mathbf{Z}\right)^{-\mathbf{1}} \mathbf{Z}^{\mathrm{T}} \mathbf{f}\right] \sim \chi_{\mathbf{p}}^{2}
$$

dengan elemen vektor $\mathbf{f}$ :

$$
f_{i}=\left(\frac{\varepsilon_{i}^{2}}{\sigma^{2}}-1\right)
$$


keterangan:

$$
\begin{array}{ll}
\sigma^{2} & =\text { Nilai varians dari model yang akan diuji } \\
\varepsilon_{i} & =\text { Error untuk observasi ke- } i \\
\mathrm{Z} & =\text { Matriks berukuran } n \mathrm{x}(\mathrm{k}+1) \text { yang berisi vektor konstan }
\end{array}
$$

Keputusan: $\mathrm{H}_{0}$ ditolak jika $B P>\chi_{\alpha, p}^{2}$

\subsection{Spasial Autoregressive Model (SAR)}

Spasial autoregressive atau spasial lag adalah model yang mengkombinasikan model regresi sederhana dengan lag spasial pada variabel dependen, Anselin[1]. Persamaan SAR aadalah sebagai berikut:

$$
y=\rho W_{1} y+X \beta+\varepsilon, \varepsilon \sim N\left(0, \sigma^{2} I_{n}\right)
$$

Estimasi parameter model SAR sebagai berikut:

$$
\begin{aligned}
& \widehat{\boldsymbol{\beta}}=\left(\boldsymbol{X}^{T} \boldsymbol{X}\right)^{-1} \boldsymbol{X}^{T}\left(\boldsymbol{y}-\rho \boldsymbol{W}_{\mathbf{1}} \boldsymbol{y}\right) \\
& \hat{\sigma}^{2}=\frac{\boldsymbol{\varepsilon}^{T} \boldsymbol{\varepsilon}}{n} \\
& \hat{\rho}=\left(\boldsymbol{y}^{T} \boldsymbol{W}_{\mathbf{1}}{ }^{T} \boldsymbol{W}_{\mathbf{1}} \boldsymbol{y}\right)^{-1}\left(\boldsymbol{y}^{T} \boldsymbol{W}_{\mathbf{1}}{ }^{T} \boldsymbol{y}-\boldsymbol{\beta}^{T} \boldsymbol{X}^{T} \boldsymbol{W}_{\mathbf{1}} \boldsymbol{y}\right)
\end{aligned}
$$

\subsection{Spasial Durbin Model (SDM)}

Model SDM merupakan model regresi spasial yang tidak hanya memiliki spasial lag pada variabel respon tetapi juga memiliki spasial lag pada variabel prediktor, LeSage[5]. Menurut LeSage \& Pace[6], model SDM memiliki bentuk persamaan sebagai berikut:

$$
\boldsymbol{y}=\rho \boldsymbol{W} \boldsymbol{y}+\boldsymbol{\alpha} \mathbf{1}_{\boldsymbol{n}}+\boldsymbol{X} \boldsymbol{\beta}+\boldsymbol{W} \boldsymbol{X} \boldsymbol{\theta}+\boldsymbol{\varepsilon}, \boldsymbol{\varepsilon} \sim N\left(0, \sigma^{2} \boldsymbol{I}_{\boldsymbol{n}}\right)
$$

atau dapat dituliskan sebagai berikut:

$$
\boldsymbol{y}=\rho \boldsymbol{W} \boldsymbol{y}+\boldsymbol{Z} \boldsymbol{\delta}+\boldsymbol{\varepsilon}
$$

dengan:

$$
\begin{aligned}
& \boldsymbol{Z}=\left[\begin{array}{lll}
\mathbf{1}_{\boldsymbol{n}} & \boldsymbol{X} & \boldsymbol{W X}
\end{array}\right] \\
& \boldsymbol{\delta}=\left[\begin{array}{l}
\boldsymbol{\alpha} \\
\boldsymbol{\beta} \\
\boldsymbol{\theta}
\end{array}\right] \\
& \boldsymbol{\alpha}=\text { Vektor parameter konstan berukuran n x 1 } \\
& \boldsymbol{\theta}=\text { Vektor parameter lag spasial variabel independen berukuran k x } 1 \\
& \mathbf{1}_{\mathrm{n}}=\text { Vektor yang berisi angka } 1 \text { berukuran n x } 1
\end{aligned}
$$

Estimasi parameter model SAR sebagai berikut:

$$
\begin{aligned}
\widehat{\boldsymbol{\delta}} & =\left(\boldsymbol{Z}^{T} \boldsymbol{Z}\right)^{-\mathbf{1}} \boldsymbol{Z}^{\boldsymbol{T}}\left(\boldsymbol{I}_{\boldsymbol{n}}-\rho \boldsymbol{W}\right) \boldsymbol{y} \\
& =\left(\boldsymbol{Z}^{T} \boldsymbol{Z}\right)^{-1} \boldsymbol{Z}^{T} \boldsymbol{y}-\rho\left(\boldsymbol{Z}^{T} \boldsymbol{Z}\right)^{-\mathbf{1}} \boldsymbol{Z}^{T} \boldsymbol{W} \boldsymbol{y}
\end{aligned}
$$




$$
\begin{aligned}
& \hat{\sigma}^{2}=\frac{\boldsymbol{\varepsilon}^{T} \boldsymbol{\varepsilon}}{n} \\
& \hat{\rho}=\left(\boldsymbol{y}^{T} \boldsymbol{W}^{T} \boldsymbol{W} \boldsymbol{y}\right)^{-1}\left(\boldsymbol{y}^{T} \boldsymbol{W}^{T} \boldsymbol{y}-\boldsymbol{\delta}^{T} \boldsymbol{Z}^{T} \boldsymbol{W} \boldsymbol{y}\right)
\end{aligned}
$$

\subsection{Pembobot Spasial}

Menurut Viton (2010), pembobot spasial adalah hubungan kedekatan (neighbouring) antara wilayah yang satu dengan wilayah lainnya. Pembobot spasial biasanya dituliskan dalam bentuk matriks sebagai berikut:

$$
\boldsymbol{W}=\left[\begin{array}{ccccc}
w_{11} & w_{12} & w_{13} & \cdots & w_{1 n} \\
w_{21} & w_{22} & w_{23} & \cdots & w_{2 n} \\
\vdots & \vdots & \vdots & w_{i j} & \vdots \\
w_{n 1} & w_{n 2} & w_{n 3} & \cdots & w_{n n}
\end{array}\right]
$$

\subsection{Pemilihan Model Terbaik}

Metode Akaike's Information Criterion (AIC) adalah metode yang dapat digunakan untuk memilih model regresi terbaik yang didasarkan pada metode Maximum Likelihood Estimation. Model yang paling baik adalah model yang memiliki nilai AIC terkecil. Menurut $\mathrm{Hu}[3]$, rumus umum AIC ditunjukkan dalam persamaan berikut:

$$
A I C=-2 \log (L(\hat{\theta} \mid y)+2 k
$$

dimana: $L(\hat{\theta} \mid y)=$ Fungsi likelihood parameter yang di estimasi

$k \quad=$ Jumlah parameter yang di estimasi

\section{Metodologi Penelitian}

\subsection{Sumber dan Variabel Penelitian}

Data yang digunakan pada tugas akhir ini adalah data sekunder yang diperoleh dari Badan Pusat Statistik (BPS) Provinsi Jawa Tengah untuk periode tahun 2015. Variabel yang akan digunakan dalam penelitian ini adalah variabel yang terdiri dari 1 variabel dependen (y) dan 5 variabel independen (x) dengan y adalah jumlah penderita DBD, $x_{1}$ adalah kepadatan penduduk, $x_{2}$ adalah jumlah rumah sakit, $x_{3}$ adalah jumlah penduduk, $\mathrm{x}_{4}$ adalah jumlah puskesmas dan $\mathrm{x}_{5}$ adalah rata-rata lama sekolah.

\subsection{Langkah Analisis dan Flow Chart}

Langkah-langkah analisis dapat dilihat dalam Flow Chart Gambar 1. 


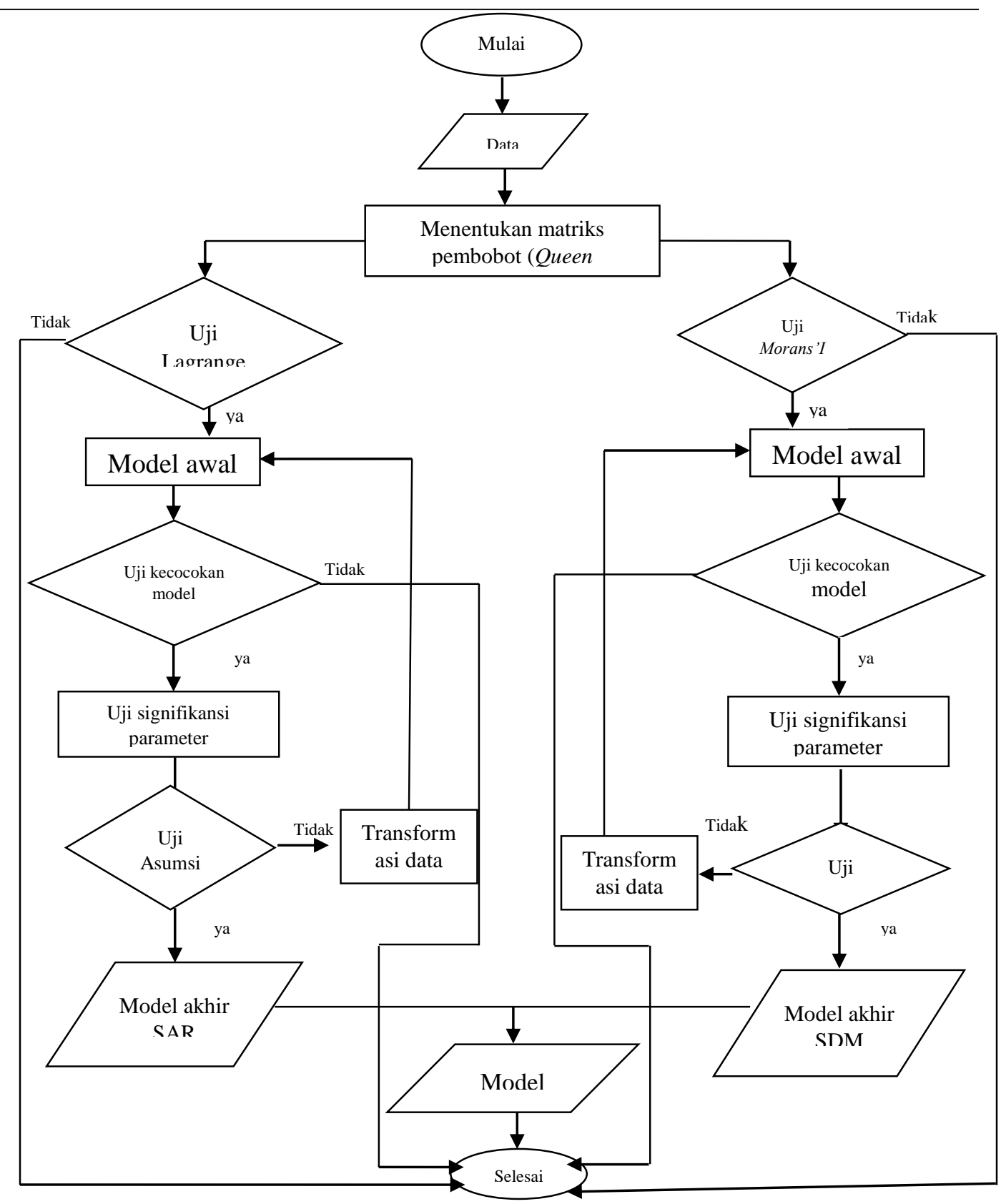

Gambar 1 Diagram Alur Penelitian

\section{Hasil dan Pembahasan}

\subsection{Analisi Regresi Berganda}

Model yang terbentuk pada analisis regresi berganda adalah sebagai berikut:

$$
\hat{y}=-1088,894+0,001 x_{3}+122,482 x_{5}
$$

Berdasarkan hasil pengolahan diperoleh kesimpulan bahwa pada uji signifikansi regresi model regresi berganda telah sesuai untuk menggambarkan hubungan antara 
variabel dependen dan independen. Pada uji koefisien regresi secara individual variabel $\mathrm{x}_{3}$ dan $\mathrm{x}_{5}$ berpengaruh sinifikan terhadap model regresi. Asumsi normalitas, non autokorelasi dan multikolinearitas terpenuhi.

\subsection{Pembobot Spasial (W)}

Matriks pembobot spasial dapat digambarkan dengan menggunakan grafik connectivity yang dapat dilihat pada gambar dibawah ini:

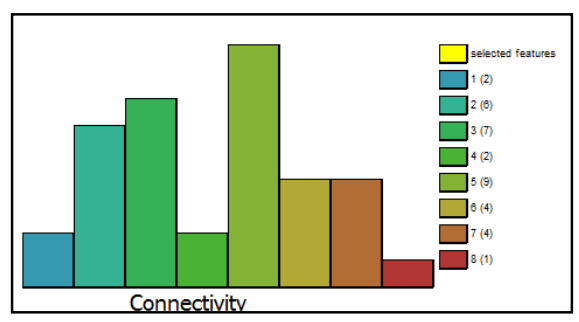

Gambar 2 Grafik Connectivity

Gambar 2 menginformasikan tentang connectivity antar daerah. Warna grafik menunjukkan banyaknya hubungan neighbouring/ketetanggaan, sedangkan tinggi grafik menunjukkan frekuensi/jumlah daerah.

\subsection{Uji Lagrange Multiplier Lag ( $\left.\mathrm{LM}_{\text {lag }}\right)$}

Dari Output diperoleh bahwa p-value LM-lag adalah 0,0021343. Nilai tersebut kurang dari $(\alpha=0,05)$, sehingga diputuskan untuk menolak $\mathrm{H}_{0}$ yang berarti bahwa terjadi dependensi spasial lag. Sehingga pemodelan Spatial Autoregressive Model (SAR)/ Spatial Lag Model (SLM) dapat dilakukan.

\subsection{Spatial Autoregressive Model (SAR)}

Diperoleh model awal SAR sebagai berikut:

$$
\hat{y}_{i}=0,55648 \sum_{j=1}^{n} w_{i j} y_{j}-1219,4+0,0006378 x_{i 3}+109,41 x_{i 5}
$$

dengan $w_{i j}$ adalah pembobot queen contiguity.

\subsubsection{Pengujian Model SAR}

\section{(a) Uji Kecocokan Model SAR}

Dari output diperoleh nilai $\mathrm{F}_{\text {hitung }}=17,94819$ dimana nilai tersebut lebih besar dari $\mathrm{F}_{\text {tabel }}=2$,911334. Jadi, dapat disimpulkan bahwa model SAR telah sesuai untuk menggambarkan hubungan antara variabel dependen dan variabel independen.

(b) Uji signifikansi Model SAR 
Tabel 2 Uji Signifikansi Parameter Model SAR

$\begin{array}{ccc}\text { Parameter } & \text { Koefisien } & \text { p-value } \\ \text { Rho } & 0,55648 & 0,0010823 \\ \text { Intercept } & -1219,4 & 0,00007387 \\ \boldsymbol{\beta}_{3} & 0,0006378 & 1,277 \times 10^{-9} \\ \boldsymbol{\beta}_{5} & 109,41 & 0,001429\end{array}$

Berdasarkan Tabel 2 dapat dilihat bahwa parameter $\rho$, intercept, $\beta_{3}$ dan $\beta_{5}$ berpengaruh signifikan terhadap model karena memiliki nilai $p$-value kurang dari 0,05 .

\subsubsection{Uji Asumsi Model SAR}

\section{(a) Uji Normalitas}

Berdasarkan output diperoleh bahwa nilai sig. $(\mathrm{K}-\mathrm{S})=0,200>\alpha=0,05$ dan dari grafik Q-Q plot dapat dilihat bahwa plot-plot menyebar disekitar garis normal. Sehingga dapat disimpulkan menerima $\mathrm{H}_{0}$ yang berarti bahwa residual mengikuti distribusi normal.

\section{(b) Uji Heterogenitas Spasial}

Dari output diperoleh bahwa nilai Breusch-Pagan Test sebesar 11,3417 dimana nilai tersebut lebih dari $\left(\chi_{0,05 ; 2}^{2}=5,991\right)$ dan $p$-value sebesar $0,003445>\alpha=0,05$. Sehingga dapat disimpulkan bahwa terdapat heterogenitas spasial.

\subsection{Spatial Durbin Model (SDM)}

Diperoleh model awal SDM sebagai berikut:

$$
\begin{gathered}
\hat{y}_{i}=0,61347 \sum_{j=1}^{n} w_{i j} y_{j}-536,42+0,00067379 x_{i 3}+125,78 x_{i 5} \\
-0,00027639 \sum_{j=1}^{n} w_{i j} x_{j 3}-80,857 \sum_{j=1}^{n} w_{i j} x_{j 5}
\end{gathered}
$$

dengan $w_{i j}$ adalah pembobot queen contiguity.

\subsubsection{Pengujian Model SDM}

\section{(a) Uji Kecocokan Model SDM}

Dari output diperoleh nilai $F_{\text {hitung }}=11,1435$ dimana nilai tersebut lebih besar dari $F_{\text {tabel }}=2$ 2,545386. Dapat disimpulkan bahwa model SDM telah sesuai untuk menggambarkan hubungan antara variabel dependen dan variabel independen.

(b) Uji signifikansi Model SDM 
Tabel 3 Uji Signifikansi Parameter Model SDM

\begin{tabular}{|ccc|}
\hline Parameter & Koefisien & $\boldsymbol{p}$-value \\
\hline Rho & 0,61347 & 0,00048795 \\
Intercept & $-536,42$ & 0,4177897 \\
$\boldsymbol{\beta}_{3}$ & 0,00067379 & $9,773 \times 10^{-}$ \\
$\boldsymbol{\beta}_{5}$ & 125,78 & 0,0006947 \\
$\boldsymbol{\theta}_{3}$ & $-0,00027639$ & 0,2660222 \\
$\boldsymbol{\theta}_{5}$ & $-80,857$ & 0,3239551 \\
\hline
\end{tabular}

Berdasarkan Tabel 3 dapat dilihat bahwa parameter $\rho, \beta_{3}$ dan $\beta_{5}$ berpengaruh signifikan terhadap model karena memiliki nilai $p$-value kurang dari 0,05 . Tidak adanya lag variable independen dengan pembobot yang signifikan menyebabkan hasil estimasi parameter menggunakan SDM menjadi tidak signifikan akan tetapi pada identifikasi nilai Moran's I mengidentifikasikan adanya dependensi spasial pada variable independen.

\subsubsection{Uji Asumsi Model SDM}

\section{(a) Uji Normalitas}

Berdasarkan output dapat dilihat bahwa nilai sig. $(\mathrm{K}-\mathrm{S})=0,195>\alpha=0,05$ dan dari grafik Q-Q plot dapat dilihat bahwa plot-plot menyebar disekitar garis normal. Sehingga dapat disimpulkan menerima $\mathrm{H}_{0}$ yang berarti bahwa residual mengikuti distribusi normal.

\section{(b) Uji Heterogenitas Spasial}

Dari output diperoleh bahwa nilai Breusch-Pagan Test sebesar 14,2548 dimana nilai tersebut lebih dari $\left(\chi_{0,05 ; 4}^{2}=9,488\right)$ dan $p$-value sebesar $0,006525>\alpha=0,05$. Sehingga dapat disimpulkan bahwa terdapat heterogenitas spasial.

\subsection{Pemilihan Model Terbaik}

Pemilihan model terbaik memakai kriteria nilai AIC. Berikut ini adalah perbandingan nilai AIC antara model SAR dan SDM. 
Tabel 4 Nilai AIC SAR dan SDM

\begin{tabular}{ccc}
\hline No & Model & AIC \\
\hline $\mathbf{1}$ & Spasial Autoregressive Model & 491,61 \\
$\mathbf{2}$ & Spasial Durbin Model & 494,12
\end{tabular}

Dari Tabel 4 diperoleh bahwa nilai AIC yang paling kecil adalah model SAR, sehingga dapat disimpulkan bahwa model SAR lebih baik dalam menganalisis faktor-faktor yang mempengaruhi penyebaran penyakit DBD.

\section{Kesimpulan}

Dari hasil analisis dan pembahasan yang telah dilakukan pada bab sebelumnya, dapat diambil beberapa kesimpulan yaitu:

1. Faktor-faktor yang secara umum mempengaruhi penyebaran penyakit DBD di Provinsi Jawa Tengah adalah jumlah penduduk dan rata-rata lama sekolah.

2. Penyebaran penyakit DBD di Jawa Tengah serta beberapa faktor yang mempengaruhinya memiliki efek spasial sehingga pemodelan untuk SAR dan SDM dapat dilakukan.

3. Berdasarkan nilai Akaike Information Crietrion (AIC) pemodelan dengan SAR lebih baik dibandingkan dengan SDM dalam penentuan model faktor-faktor yang berpengaruh terhadap penyebaran penyakit DBD di Provinsi Jawa Tengah.

\section{Daftar Pustaka}

[1] Anselin, Luc. 2003. A Companion to Theoretical Econometrics. UK: Blackwell Publishing L.td.

[2] Gujarati, Damodar N.. 1978. Ekonometrika Dasar. Jakarta : Erlangga.

[3] Hu, Shuhua. 2007. Akaike Information Criterion. North Carolina State University.

[4] Kleinbaum, David G et al. 2014. Applied Regression Analysis and Other Multivariable Methods, Fifth Edition. Boston: Cengage Learning.

[5] LeSage, James P..1999. The Theory and Practice of Spatial Econometrics. Department of Economics, University of Toledo.

[6] LeSage, J., Pace, R.K.. 2009. Introduction to Spatial Econometrics. Taylor \& Francis Group. USA.

[7] Montgomery, Douglas C., Runger, George C.. 2011. Applied Statistics and Probability for Engineers. John Wiley \& Sons, Inc. USA. 